Please do not remove this page

RMIT

UNIVERSITY

\title{
Indian students in Melbourne: Challenges to multiculturalism
}

Singh, Supriya

https://researchrepository.rmit.edu.au/esploro/outputs/9921858438201341/filesAndLinks?institution=61RMIT_INST\&index=null

Singh, S. (2011). Indian students in Melbourne: Challenges to multiculturalism. Journal of Intercultural Studies, 32(6), 673-689. https://doi.org/10.1080/07256868.2011.618110

Document Version: Submitted Version

Published Version: https://doi.org/10.1080/07256868.2011.618110

Repository homepage: https://researchrepository.rmit.edu.au

(C) Copyright 2011

Downloaded On 2023/04/26 13:49:24 +1000

Please do not remove this page 


\title{
Indian students in Melbourne: Challenges to multiculturalism
}

\author{
Supriya Singh \\ Graduate School of Business and Law, RMIT University, Melbourne, Australia
}

The migration experiences of Indian students challenge traditional frameworks of multiculturalism in Australia in four ways. Firstly, unlike earlier groups of migrants, Indian students pay to study hoping to become migrants. Indian families contributed A \$2.9 billion to Australia for educational fees, living expenses and tourism in December 2010 and generated 28,975 full time equivalent jobs. Secondly, student narratives are those of mobility and greater options rather than settlement. Thirdly, Indian international students belong to a middle-income country which is an important trading partner for Australia in a century dominated by Asia rather than the United States and Europe. And lastly, like other migrants, the students live in transnational families that go beyond the traditional national framework of multiculturalism. I draw on 35 openended individual and group interviews with Indians who arrived on student or spouse visas in 2005 or later and 12 persons who occupy leading positions in Indian community organisations, media and local government.

Keywords: Indian students; Australia; racism; multiculturalism; mobility

\section{Introduction}

In 2009 and early 2010 the Indian media ran news of Indian international students being robbed, assaulted and killed in Australia, particularly in Melbourne. Victoria Police said that 1,447 Indians were victims of reported crime in Victoria, in the year ending July 2008. There is as yet no definitive analysis of the circumstances of the crimes, or the ethnicity of the victims or of the assailants. It is known that many of the assailants were young people. It is also speculated that they were from other migrant groups (Singh and Cabraal 2010). In Sydney, there has been particular mention of racist attacks being perpetrated by Lebanese Australian youth in central Western Sydney (Dunn, Pelleri, and Karin 2011). 
Australian governments at the state and federal level, together with the education industry, have generally denied the existence of racism, blaming the victims and labelling the crimes as 'opportunistic', or arguing that some degree of violence is 'normal' in Australian cities. This denial of racism appears to be supported by other authorities (see also Dunn and Nelson, this issue).

Dunn et al. (2011) say, 'The denial of racism is a familiar hallmark of contemporary racism...' (p. 72). They argue these racist attacks against Indian students have to be evaluated in the context of a 'ten-year period of concerted undermining of multiculturalism and anti-racism’ (ibid., p. 72). There was an 'undermining of multiculturalism and anti-racism programs during the Howard Coalition Government (1996-2007)’ (p. 73). Subsequent Labor Governments have not reversed this trend, apart from a broad declarative support for multiculturalism publicised in February 2011 (see Introduction to this issue).

The racist attacks against Indian international students, and the overall denial of racism have economic implications for Australia because they affect the country's international reputation. This in turn influences the intake of fee-paying international students to Australian educational institutions and also the country's ability to source scarce skilled labour from overseas. However, the threat of economic losses for the education sector, the fourth largest export earner, did not lead to immediate acknowledgement and firm action against racist violence. Educational institutions have also not taken sufficient action to increase their duty of care and international student security (Marginson et al. 2010).

\section{Multiculturalism}

In the 1970s, Australia broke with its White Australia Policy and at the same time embraced multiculturalism rather than focusing on the assimilation of immigrants. 
The country had become more multicultural as a result of large waves of post Second World War migration. Hage (2008) points out that multiculturalism goes beyond the 'the mere existence of cultural heterogeneity and diversity’ (p. 492) or cultural pluralism. Multiculturalism comes about when cultural diversity encounters a multicultural sensibility. This in turn is the result of three factors: 'the dominance in the post-World-War-II era of a "relaxed" form of nationalism... the rise of cosmopolitanism as a popular aspiration and ... the popularization of "sociological" modes of thinking' (ibid., p. 493) relating to social justice.

Hage says multiculturalism 'is a relationship between the individual and the nation state' (p.499). He argues that...

...multiculturalism is primarily a mode of integrating third-world-origin citizens into the Western nation-state ... There is a commitment to provide spaces of cultural self-expression and realization for these individuals. But this has been so only in so far as the laws operating within those spaces do not come in conflict with the all-encompassing national laws (p. 500).

Multiculturalism recognises the differences of migrants who are new to the country, and thus is anti-racist. However, this recognition of difference is very much in the context of the 'the centrality of white Europeans' entitlement to the nation' (Hage 2008, p. 503). Economic globalization and the rising economic strength of China and India question the ‘centrality’ of the white European worldview.

A growing insecurity among White Europeans has eroded some of the conditions that supported multicultural policy. This is despite Australia's need to present itself as cosmopolitan in order to access migrant skilled labour for economic growth. At the same time, as I shall argue below, some of the assumptions about migrants that are embedded in multiculturalism no longer hold. 


\section{Attitudes to immigration and experiences of racism}

Though over the past 15 years politicians rarely spoke of multiculturalism Markus (2010) notes that, 'the general disposition of Australians towards immigration has become more positive over time' (p. 9). This positive finding comes at a time when the balance between permanent and temporary migrants has shifted, so that today it is the temporary workers who make up the larger portion of the immigration intake. The other main shift since the 1960s is that the largest proportion of migrants come from Asia and Oceania rather than Europe (Markus, Jupp, and McDonald 2009).

Drawing on the second Scanlon Foundation Survey, conducted in 2009, Markus found that despite this overall positive attitude to immigration, a majority of all those surveyed were in favour of limiting the rights of asylum seekers arriving by boat. Attitudes towards immigration were also more negative among respondents born in Australia and with both parents born in Australia who live in areas of high immigrant concentration.

The overall support for a diverse immigrant intake is accompanied by ten per cent of people surveyed saying they had experienced discrimination in the last 12 months. This compared with 15 per cent in areas of high immigrant concentration. People born in India and Sri Lanka reported the highest level of discrimination at 20 per cent, followed by China and Vietnam at 19 per cent (Markus 2010).

Other surveys present higher figures for racist experiences of Indians and Sri Lankans in Australia. Dunn et al. (2011) drawing on an analysis of telephone surveys carried out between 2001 and 2008, state:

The experience of racism among Indians/Sri Lankans was prevalent in public spaces, such as shops and restaurants (43 per cent of respondents), the workplace (41 per cent) and sporting or public events (39 per cent). The rates of reported experience of racism among respondents in seeking accommodation and in education were close to one in three (28 per cent)(p. 79). 
Against this background of racism against Indian international students, multiculturalism and attitudes to immigration, I proceed to outline how I studied Indian students. I then analyse the student migrant experience, drawing out four main themes and differences between recently arrived Indian students and earlier Indian migrants who arrived from the 1970s to the 1990s. The Indian students usually migrate in a two-step process. They pay for an Australian education before being able to apply for permanent residence. Their narratives however are those of mobility rather than settlement. They are supported by the Indian government which sees itself as a rising global economic power able to protest against the abuse of its citizens. And finally, as with all migrants, the discourse is one of transnationalism as well as adjustment to Australia.

\section{Studying Indian students}

For this study, 35 Indian students or student migrants were interviewed either individually (9), as married couples interviewed together (4) or in groups (22) between October 2009 and June 2010. All the students interviewed had arrived in Australia in 2005 or afterwards on a student or spouse visa.

The interviewees are from a range of backgrounds and length of stay. The sample reflects the dominance of people from Punjab, males in their 20s, and current study in private colleges. Five of the six university students arrived in Australia in 2005, and the sixth one came in 2006. The sample is more heavily weighted towards married couples than the population of the Indian international students in general. Indian international students are predominantly single, but some married while in Australia. The sample also substantiates the insight that Indian international students are now being increasingly recruited in smaller towns and villages rather than Indian 
metropolitan cities. Seven of the nine persons who came from villages arrived in 2008 or afterwards. In this sense our sample is different from that of Baas (2010) who studied Indian students in 2005-2006 and found that most were born in India's larger cities.

In our sample, 15 of those aged 18-24 came to Australia from 2007 onwards. Twenty five of the 35 participants have a Bachelors degree or above. Those who came 2005-2007 furthered their education in Australia. Most of those who came after 2007 enrolled in cooking, hospitality or community welfare jobs as an easy route to Permanent Residency (PR). The students continue to come predominantly from the ranks of Indian upper-middle and middle class. However unlike Baas' (2010) study of Indian students in 2005-2006, many of our students had not studied in English medium schools and had not spoken English with family and friends. Thirteen of the 35 interviews were conducted wholly or mainly in Punjabi rather than English.

Table 1: Characteristics of the sample of Indian international students and student migrants

\begin{tabular}{|c|c|}
\hline Characteristic & Number $(\mathrm{n}=35)$ \\
\hline Region in India & 16 \\
Punjab & 3 \\
Other North India & 3 \\
Gujarat & 11 \\
Andhra & 2 \\
Kerala & \\
Male & 25 \\
Female & 10 \\
\hline Gender & \\
Metropolitan city & 4 \\
Regional city & 12 \\
Town & 3 \\
Village & 9 \\
Did not ask & 7 \\
\hline
\end{tabular}




\begin{tabular}{|c|c|}
\hline Characteristic & Number $(\mathrm{n}=35)$ \\
\hline Age & $\begin{array}{r}13 \\
19 \\
3\end{array}$ \\
\hline $\begin{array}{l}\text { Educational background in India } \\
\text { High School Certificate (Plus 2) } \\
\text { Diploma } \\
\text { Bachelors/Arts/Science/Engineering } \\
\text { Masters }\end{array}$ & $\begin{array}{r}6 \\
3 \\
18 \\
7\end{array}$ \\
\hline $\begin{array}{l}\text { Year of arrival } \\
2005 \\
2006 \\
2007 \\
2008 \\
2009 \\
2010\end{array}$ & $\begin{array}{r}7 \\
2 \\
6 \\
17 \\
1 \\
2\end{array}$ \\
\hline $\begin{array}{l}\text { Place of study } \\
\text { Private institute } \\
\text { University affiliated private } \\
\text { institute } \\
\text { University } \\
\text { Spouse }\end{array}$ & $\begin{array}{l}24 \\
1 \\
6 \\
4\end{array}$ \\
\hline $\begin{array}{ll}\text { Religion } & \\
& \text { Sikh } \\
& \text { Hindu } \\
& \text { Christian } \\
& \text { Muslim }\end{array}$ & $\begin{array}{r}17 \\
15 \\
3 \\
\text { Nil }\end{array}$ \\
\hline $\begin{array}{l}\text { Parents' class background (self ascribed) } \\
\text { Class background } \\
\text { Upper-middle class } \\
\text { Middle class } \\
\text { Lower-middle class } \\
\text { Not established }\end{array}$ & $\begin{array}{r}17 \\
12 \\
1 \\
5(3 \\
\text { farmers and } \\
\text { landlords, } 1 \\
\text { Assistant } \\
\text { Textiles } \\
\text { Manager and } 1 \\
\text { parents } \\
\text { occupation not } \\
\text { asked) }\end{array}$ \\
\hline $\begin{array}{c}\text { Migration status of participants } \\
\text { Australian Citizen } \\
\text { Permanent Resident } \\
\text { Have applied for PR } \\
\text { Student/Spouse Visa }\end{array}$ & $\begin{array}{r}4 \\
2 \\
5 \\
20 / 4\end{array}$ \\
\hline
\end{tabular}




\begin{tabular}{|l|c|}
\hline Characteristic & Number $(\mathrm{n}=35)$ \\
\hline Single & 19 \\
Married & 15 \\
Single parent & 1 \\
\hline
\end{tabular}

The study of the Indian students was supplemented by interviews with 12 Indian leaders of community and religious organisations, media and government. The Indian student study is part of a wider study of the Indian diaspora in Australia which began in May 2005 (see Table 2).

Table 2: Characteristics of the diaspora sample

\begin{tabular}{|l|l|}
\hline Group & Number \\
\hline First generation & 18 \\
\hline Second generation $^{1}$ & 20 \\
\hline Student migrants $^{2}$ & 35 \\
\hline Community leaders and representatives & 13 \\
\hline Total & 86 \\
\hline
\end{tabular}

${ }^{1}$ Those who were born here or migrated with their families before they were 12 years old.

${ }^{2}$ Those who came on a student or spouse visa in 2005 or later.

The approach to the study was that of grounded theory, moving from data to theory. The interviews were transcribed and analysed using NVivo 8, a computer program for the analysis of qualitative research.

\section{Indian students' migrant experience}

Indian students' migrant experience is significantly different from that of the Indians who migrated between the 1970s and 1990s. Most of the earlier migrants that now comprise the settled Indian community in Australia were English-speaking 
professionals from metropolitan cities who mainly migrated as families. They came to jobs or soon secured work in their fields of expertise.

The recently arrived Indian students are mainly single males in their 20s and increasingly coming from regional cities, small towns and villages. They have to pay for their education as well as living expenses to qualify for possible migration. Their experience has been marked by racism. At the same time there is a disconnect between them and the settled Indian community as well as the second generation Indians in Australia (Singh and Cabraal 2010). However, for many Indian students, work in non-Indian workplaces has also led to strong relationships with people from other backgrounds.

\section{Experience of racism}

Harbinder, ${ }^{1} 29$ years old, from an upper middle-class family in northern India came to study in Australia in January 2009. She had already completed her Bachelors in Education and another Masters degree. She was working in Delhi and came to Australia to escape family pressure to get married. She says she got off the train, after a late shift at work to West Footscray at $12.30 \mathrm{am}$, and was set upon by four men.

... I don't know what nationality they were, but they were funkily dressed up, with coloured hair and they were boozed. One of the guys grabbed me from my back, held me. I started screaming ...He clutched my arms, so I was really struggling to get my phone out. Because my roommate's phone was on the speed dial, it accidentally got dialled to her. ... They thought I'd called the cops and they just left me there and ran away.

She reported it to the police the next day. The policeman asked '”Did they steal anything from you? Did they take your money away?” I’m like, “No, but isn’t this enough that my knees are bruised?” So he’s like, “Well, there are no cameras there”.'

\footnotetext{
${ }^{1}$ The names of the participants are pseudonyms.
} 
The next time she experienced violence was in mid-2010 when she was at a tram stop in the cosmopolitan inner-city beach suburb of St. Kilda at 3pm. A woman was sitting there reading a Hindi religious text. So Harbinder started speaking to her in Hindi. A man, obviously drunk, said "Hey, you should just leave my country. Why are you talking in your language?”

Harbinder's story is unusual in that she is one of the few women among our participants who speaks of racist abuse and violence. She is also older than the average Indian international student. But she is not unusual in having experienced racism on the streets of Melbourne. Half the 35 participants had either experienced racist abuse or violence (seven participants) or said their close friends, family, fellow students or housemates had experienced racist violence (11 participants). Students in our sample said that many incidents were not reported because of perceived police inaction. Seven of those who had experienced or heard of racist abuse said the police did not act, or that they began questioning the victim as if s/he was the perpetrator.

These stories of racism also reveal Indian students' 'black and white' image of the ethnic categories in Australia. The participants who spoke in Punjabi used the terms gorai (white) and kalai (black) to talk of the perpetrators. Australia was divided into 'pure Australians' or 'real Australians' referring to those 'born in Australia' or those who have lived 'in this country for more than 20 years [and have] a British origin’. Most often Australia and Australians were seen to be good, for the problem was with the 'others', that is, the 'new migrants'.

Though nearly half the participants told stories of racist abuse and violence, only two of our participants were thinking of moving away because of racism - one from Melbourne to Perth, and one returning to India. Two said that the racism in India was worse. Another said he was taken aback when one of his Australian customers at 
his shop accused the Indians of being racist, saying: 'You guys have your own businesses, you hire only Indians. In Australian businesses we hire everybody’.

\section{Indian students and the wider Indian community}

The students' most important relationships in Australia are with other Indian students and recent migrants they knew from India. The majority of our participants named only Indians among their five friends in Melbourne. This was because their world was totally Indian in terms of study, living arrangements and employment, or because study and the workplace had not led to meaningful relationships in the wider community.

Many of these relationships with other students and recent migrants from India stand in the place of absent family ((Marginson et al. 2010; Baas 2010). However, not all these relationships are positive. Harbinder said that on her first day on a train in Melbourne, a Punjabi student sitting opposite her asked courteously whether she was new and was looking for work and accommodation. When she confirmed, he said: “I'll look after you. All you have to do is sleep with me.” Others reported scams related to farm work or the push for jobs. For the most part though, other Indian international students were at the core of their relationships in Australia.

Most of the Indian students spoke of a disconnect with the settled Indian community, that is, Indian professionals who migrated to Australia in the 1970s, 1980s and 1990s. Recent Indian students do not connect closely with the second generation Indians and Indian community organisations either (Singh and Cabraal 2010). The Indian established community has set up some structures of support for the recently arrived students, but most of these have failed the students. Four of the 35 participants were closely connected to Indian community organisations - one through hockey, two through Gujarati dance and one through voluntary work. And for two of 
the three Christian students in our sample, churches figured prominently in their stories of support.

For many Indian students their direct experience of the wider Indian community is the temple and/or the Indian restaurant. The temples are places of comfort, sometimes help, but seldom lead to relationships between Indian international students and the established Indians. The church was seen as supportive by two of three Christians in our sample. There were no Muslims in our sample.

\section{Indian restaurants as employers}

Indian students who were financially constrained, and whose poor English and/or lack of prior experience made it unlikely for them to find jobs with non-Indian employers, sought work with the Indian restaurants. Of the seven students who worked or inquired about work in an Indian restaurant only one reported a positive experience. After he had worked there for a while, he began to earn $\$ 10$ an hour (which is below the minimum Australian wage). The others who have worked in Indian restaurants spoke of exploitation due to very low wages, and a sense of helplessness. A leader of an Indian religious organisation in Melbourne said they had taken steps to combat this exploitation, but not one student was willing to formally complain of low or no payments. None of our participants were working in Indian restaurants at the time of the interview.

The experience of Indian students in the workplace is in tune with that of international students in general. Marginson et al (2010) in their study found that of the students who reported their hourly rate, ‘58 per cent earned between \$7 and \$15 per hour at a time when the legal minimum wage was $\$ 16.08$ an hour for a casual waiter' (p. 136). The Chinese students they interviewed were particularly scathing about work conditions in Chinese restaurants and workplaces. The government has 
ignored the abuses in the employment of international students and has done little to prosecute the offending employers.

The Indian students who spoke with us did not place their experiences in the wider labour market perspective. They saw it in terms of a negative encounter with their own community.

Sharan, 19 said, 'I work in an Indian home all day for $\$ 30$ a day, 7am to 4pm. ... There is no other work that I can find'. Samarjit, a man in his mid 20s worked in an Indian restaurant for two weeks before moving on to a Greek restaurant. He said, 'Only Indians do this. The white people are very fair'. Sharan concured by saying 'I clean for a white woman. She gives me \$12 an hour'.

Shinder, 19, arrived in Melbourne in 2010, after finishing her high school, from a village in Punjab. Her experience with Indian restaurants is typical of the stories the other students told. The job in the Indian restaurant is often the first job the students can get, particularly if their English is weak. The wages are low, training gets extended, and the hours are long. An Indian ex-restaurant owner admits that some places do exploit their staff. She has found the students she hired to be hard working, but also knows of cases where the Indian students have tried to falsely claim hours of work experience in their field.

\section{Relationships with people from non-Indian backgrounds}

As discussed above, the majority of our participants did not name any non-Indians among their five friends in Melbourne or mentioned people of other communities except when talking of racism. However, 11 of the 35 participants spoke of intercultural relationships through the workplace and the university. For three of these 11, their non-Indian relationships were central to their support networks. 
Ekta, in her late 20s, came to Melbourne in November 2005. Now working in an educational institution, she told a story of a rushed marriage that disintegrated within three years. By this time she already had Permanent Residence (PR) on the basis of her Masters in Accounting and another in Finance in India and three years' work at a financial centre in Punjab. In August 2008, Ekta and her daughter walked out of the marital home because of domestic abuse. During the hard times, the main sources of support were her mother and sister who came to Australia, a cousin in Sydney, a childhood friend and colleagues at work in National Australia Bank (NAB) and Coles.

Ekta was close to tears most of the time during the interview, but particularly when she was recounting Australians' kindness to her. The manager at Coles, the local supermarket, knew of her troubles, and she remains close to him, his wife and daughter, visiting at birthdays and for lunch. Later, her boss at National Australia Bank (NAB) and the team - they told her they would work around her schedules, and she had all the flexibility she needed to pick up her daughter from childcare by 6pm. As she did not have a car, some of her team mates would go shopping for her daughter and buy her daughter gifts during their lunch hour. Among her closest friends are these Australians, a South Indian woman, and a Greek neighbour.

Jay, in his late 20s, studying commercial cookery and working in an international hotel, met Australians at work and socialised with them outside work hours. Chandra, in his early 20s, also meets his work colleagues after work. Chandra completed his university studies in Melbourne, and is now working as a business analyst. Despite this social interaction with non-Indians, their main friendship groups remain Indian, often from their own part of the state and with some links in India. Indu and Inder, a married couple from Gujarat in their mid-20s, have also made 
friends through Inder's workplace in the transport industry. They are both vegetarians and they talk of how their Greek and Lebanese colleagues make vegetarian curries and barbeques when they invite them to their homes. They also mention Vietnamese and Pakistani friends. Charandeep, 31, and Amar, 27, both working at universities, also had friends from other backgrounds.

For Ravi and Kailash, both from the Indian state of Kerala, Australians have been the main support group. Ravi, in his early 30s, met them while cleaning a butcher's shop. He has been to their homes for parties and Christmas, and in turn invited them to his place to celebrate Onam, the Kerala New Year.

Kailash, in his late 20s, was even more deeply connected with non-Indian Australians for he lived with them soon after he arrived in Melbourne. He speaks in heavily accented English. A shop owner put him in touch with a disabled pensioner of Scottish background who had a room to let. Kailash stayed with him for three months. They went to church together. Kailash cooked and during this period they shared 23 bottles of wine. During the interview he showed me a picture of the 23 bottles of wine on his mobile phone. As the house was going to be sold, Kailash let it be known through the Church newsletter that he was looking for a place. Three weeks later an older Australian (Dutch/Irish background) family called to offer him a place for $\$ 150$ a month. He sees them as his foster grandparents. 'Yeah, they treat[ed] me as a grandson', he said.

While he was living there, his foster grandparents and two other families bought him a bicycle to go to work. When Kailash moved to the country to work in an aged care facility, they bought him a small bar fridge, a new microwave and gave him two couches and a TV. Again, through the priest, he now shares a house with an Australian woman for \$200 a month. 


\section{The Verdict}

Most of the Indian students and student migrants in this study have come through their difficult early years and dealt with financial stress in addition to the difficulties of settling in a new country. All the students with loans are repaying their student loans, while three are also able to send some extra money home. Despite their troubles, their experience has led to greater work skills, income, a greater reliance on one's self and/or spouse, and dignity of work. The recurring theme is that they have learnt to be independent and not rely wholly on their families.

Of the seven who came in 2005, six are in professional jobs and the seventh who studied cookery is working in a Chinese restaurant. Two of these students got married and brought their wives to Australia. Six have citizenship or permanent residence (PR), and one has applied for PR and is waiting to hear. Champesh, in his early 20s who works in customer relations, and Chandra, also in his early 20s, a business analyst, have both bought homes in Melbourne and feel they belong.

Of the 20 students who came in 2008 and later, 11 have employment which pays award wages. Those who came with substantial employment experience and good English have slotted easily into international hotels in Melbourne. Two female students are still vulnerable in their employment. One is unemployed and two women whose husbands work are not seeking employment. Others like Govind are struggling with casual factory work. He says, 'In India I used to get up at 6am to play cricket. Here I wake up at 5 am to go to work'. At the time of the interview he had not told his professional parents in India that he works in a factory. He will have to tell them when they come for a visit.

Student migrants are a new kind of migrant group, created by a policy linking international education and migration since 2001. The migration of Indian students is a two-step process. They pay for their education and living expenses in order to 
qualify for the possibility of migration. This makes them consumers as well as potential migrants. Indian students are unlike post-war European migrants, Asian migrants in the 1970s to 1990s, and skilled temporary migrants who come for work.

The aim of the policy was to get ‘designer migrants’ (Simmons 1999), who would pay for their required skills and good English. The international education/migration policy led to international education becoming one of the top export earners in Australia.

Indian students’ families’ remittances are a significant part of the A $\$ 19.1$ billion to Australia as a whole in 2009-10 and the A $\$ 5.9$ billion that came from international education to Victoria alone (Australian Education International (AEI) 2011). Even with more conservative estimates of revenue, Access Economics (Access Economics Pty Limited 2009) for 2007-2008 showed that each international student contributed $\$ 28,921$ in value added to the Australian economy and generated 0.29 in full-time equivalent (FTE) workers (p. i). As there were 99, 915 Indian students enrolled in Australia in December 2010 (Australian Education International (AEI) 2011), even using 2007 estimates, it means that Indian students contributed at least $\$ 2.9$ billion to the Australian economy and generated 28,975 full time equivalent jobs.

The policy framework behind the steep increase of Indian students was opaque to the general public. There was little understanding that the international students were a new, special migrant group and that their increase was a response to government policy. Baas (2010) reports a shift between seeing Indian students as welcome 'guests' in 2005, to Australians telling him in 2008 that Indian students had 'come to Australia under false pretenses [sic], competing unlawfully for local jobs 
and taking up public space where they were supposed to "feature in the background"' (p. 4).

\section{Student narratives of mobility}

The students were attempting to gain Permanent Residence (PR) as a way of increasing their individual and family mobility and options for economic prosperity. Hence their narrative is one of mobility rather than permanent settlement in Australia. Baas (2010) is correct in pointing out that for the Indian students, the offer of a permanent residency in Australia was important, but it was at the same time an offer of transnational mobility . The earlier professional Indian migrants had decided for settlement when they migrated with their families.

For recent Indian student-migrants, the decision to move often revolved around the potential for economic success for the individual and the family. The choice for three of my respondents was between Bangalore and Melbourne. This was partly the choice that faced Gita (in her late 20s) and Govind (in his early 30s), a married couple from a regional city in Punjab. Both had a graduate education. Govind says he tried to get a job in the education sector but the permanent jobs were frozen. He then tried a call centre where the starting salary was INR $4,000^{2}$ a month (AUS\$ 83.3). This job also meant he had to move away from home. He then tried marketing but earnings were purely on a commission basis. None of these jobs would offer the middle-class life his parents had enjoyed. After two years of searching for a good job, he began thinking of migrating. He had distant relatives in Canada, but Gita had a brother in Melbourne. Govind and his father discussed the choice between Melbourne, Sydney and Bangalore, and thought that Melbourne offered the most potential, even though it was a considerable investment. Whether Gita and Govind

\footnotetext{
${ }^{2}$ On 27 May 2011, INR 100 were equal to AUS\$ 2.08
} 
and their two children stay in Melbourne, depends on whether Gita’s Community Welfare course will lead to permanent residence. In the long term, it will also depend on whether Govind's retired parents want to migrate and the family is able to pay the visa costs of roughly $\$ 80,000$ for both parents.

Charandeep, 31, who came to Australia in 2005 from a regional city in Punjab faced a similar choice. He said he could not find a job in Punjab. He said his father told him: 'If you have to go to Bangalore, you may as well go to Australia'. Family reunion was also the deciding fact for Charandeep, as he is the only son. When I interviewed him in March 2010, he said he was not trying to purchase a home for his plans were to complete his $\mathrm{PhD}$ and look for a job in Canada. He was saving his money so that he could buy a house in Canada. His parents' visa costs in Australia were higher. Moreover, they also had family in Canada. However, when I met him by chance in February 2011, he had accepted a position at an Australian university and had decided to pay the visa costs. His parents were due to visit soon, to see whether they wanted to settle in Australia.

Apart from the general context of globalisation and transnational labour market, the emphasis on mobility rather than settlement is also a reaction to changes in the link between education and migration in Australian. I interviewed a group of five students studying commercial cookery in May 2010, soon after visa conditions were tightened. In a few months, they would graduate with internationally recognised qualifications. Jay, in his late 20s, who had worked in hotels in Europe and Australia said:

We invested a lot of money and time to come here. Now they have changed the rules. At that point Australia looked very promising. Now it is not... I am a hard worker. I know that. I came out of India. I can go anywhere. 
Joshua, in his late 20s, who had engineering qualifications from India but was studying commercial cookery in Melbourne, said he had planned to stay in Melbourne. But because of the changes in February 2010 to the Migration Occupation in Demand List he will now try to go to the United States to study Information Technology. Jaidev, in his late 20s, previously worked in an international hotel in India. He said 'Canada recognises the degree. I will see if I can work there'. Jaswant in his early 20s is also investigating the options offered by Canada. Jayant, also in his early 20s, is keeping to his original plans to go back to his hometown where his family has a hospitality business. The Australian qualification will give him a global perspective that would help advance the family business in India.

There were others in the same private college who were in a limbo because they were soon to complete their education but their prospects for permanent residency had diminished. One of the students had already cancelled plans to have his family join him, even though the family’s visas had been granted. He would take advantage of the transitional period to save money to re-start his business in India.

\section{Indian students are from an emerging global power}

In 2009 and 2010, during a spate of racist violence against Indian students, one often heard comments how previous migrant groups also suffered discrimination. The argument was that it would pass, and the Indian student migrants would settle down in Australia, just as other groups had done before them.

There were two factors that set this group apart. Firstly, they were not just potential migrants, but also consumers of education services. These student migrants came from a middle-income country, from middle-income families able to pay for international education. They had invested in education and mobility, rather than coming from war-torn countries or from countries where they were escaping poverty. 
Unlike other temporary migrants who come for work, this group contributes significant amounts of revenue to Australia's education industry and the country as a whole.

Secondly, student migrants and their families had access to the powerful Indian media who could broadcast their troubles globally. Though perceived by the Victorian police and judges as 'soft targets', the Indian students have protested and rallied in the streets, and lobbied through their organisations like the Federation of Indian Students Australia (FISA). The growing importance of India and China - and Australia's economic dependence on Asia - means that racism can lead to negative economic consequences for Australia. Despite denials of racism by the Australian governments and the education industry, racist assaults against Indian students drew a quick response from the Indian media and a recently more assertive Indian government demanded respect for its citizens overseas. This paralleled the less publicised intervention of the Chinese government in 2008 who spoke out against violence against more than one in four Chinese international students in Australia (Marginson et al. 2010).

Racist attacks against Indian students have partly contributed to a 33.5 per cent decline in the number of Indian students between March 2009 and March 2011(Australian Education International (AEI) 2011). Using the 2007 estimates from Access Economics, discussed above, that each international student contributes $\$ 28,921$ in value added to the Australian economy and generates 0.29 in full-time equivalent (FTE) workers the loss of 24,715 students translates to a loss of $\$ 715$ million and 7,167 full time equivalent jobs in Australia. But perhaps more importantly, the discussion of Australian racism went global, beyond national borders, diminishing Australia's brand in education and its image as a multicultural society. 
Publicity about the racist attacks also made them a diplomatic issue between India as an emergent economic power and Australia in a century that is seen to economically belong to Asia rather than the United States and Europe. Though the centrality of the Europe-centric worldview continues to hold in Australia and may explain the lack of more forceful action against racism, it is also clear that this worldview is no longer accompanied by the surety of economic dominance.

\section{Transnational ties}

Multiculturalism privileges the diversity of cultural spaces and values over an approach advocating total assimilation. However, multiculturalism is framed very much within a national framework. It is not devised to take into account that core family and community ties are also transnational, linking families and communities across borders. These transnational ties coexist with multicultural ties within Australia As Levitt and Schiller (Levitt and Schiller 2004) argued:

The lives of increasing numbers of individuals can no longer be understood by looking only at what goes on within national boundaries. Our analytical lens must necessarily broaden and deepen because migrants are often embedded in multi-layered, multi-sited transnational social fields, encompassing those who move and those who stay behind .....Migrant incorporation into a new land and transnational connections to a homeland or to dispersed networks of family, compatriots, or persons who share a religious or ethnic identity can occur at the same time and reinforce one another (p. 1003).

The common refrain in students' stories about their experience in Melbourne is the importance of regular contact with their families, particularly in the early days when the loneliness is most intense. Like other migrants, the students live in transnational families that go beyond the nation state. These transnational relationships are very intense for the students, in that their parents are directly or indirectly supporting their study and stay in Australia. For other migrant groups, particularly those who come 
from Asia and Africa, the money goes from Australia to the home country. With the students, their families are sending money to Australia with the hope that their children will get permanent residence. The students' families provided the initial financial support in all but one case, where the student funded himself with savings from previous work in Europe. In a few cases, there continues to be family support for fees and living expenses.

This support goes beyond money and is shown in help with child care and steady emotional support through regular communication. In four cases, members of the family have visited. In two cases, the parents helped look after their grandchildren in India and later brought the grandchildren to Australia. In three instances, a grandparent stayed for permitted periods to help with the child care.

\section{Conclusion}

Indian students paint a nuanced picture of their experience in Australia. At one end, there is racism experienced directly or indirectly by half the students in this study. At the other end they are developing relationships with people of non-Indian backgrounds through work, and less often through neighbourhood and study. Multiculturalism in terms of significant relationships between people from different communities is alive, and some of the students have benefited from the kindness of strangers. In the middle is the settled Indian community that for most of the students remains apart. Even when times have been difficult for some students, they have valued their new found independence, learned the dignity of work and gained internationally recognised qualifications that equip them to compete for jobs globally and be mobile. Indian students challenge accepted frameworks of multiculturalism, 
because they are a new kind of migrant group who have paid in order to migrate and because they are part of transnational and global frameworks.

The Indian students are also different because they are backed by the powerful Indian media and belong to a country that is growing in assertiveness and economic importance. Racism and multiculturalism used to be seen as cultural and political phenomena. Racism now has direct and indirect global economic implications. It has cost Australia in terms of its international reputation, its education service industry and ultimately its ability to attract young, skilled labour.

The Indian student migrants have also challenged the importance of the national framework for multiculturalism. The strength of transnational ties ensures the debate no longer is one between assimilation and multiculturalism. Indian students also challenge national frameworks for their emphasis is on global mobility rather than just permanent settlement in Australia. They chose education in Australia, judging it will be the pathway for greater economic security and flexibility for themselves and their families. Facing the prospect of policy changes that endanger economic mobility or the togetherness of the family, they are re-evaluating their prospects within a global framework. Though the policy linking international students and migration was geared to providing 'designer migrants', the students are seeking a 'designer settlement country', where the prospects are good for individual and family prosperity.

\section{Acknowledgements}

I would like to acknowledge the contribution of Dr Anuja Cabraal. She conducted and coded two group interviews with five students and interviewed three community leaders. She was part of the Indian diaspora study team. I also gratefully acknowledge the support of the Global Cities Research Institute for its continued support of the Indian diaspora project.

\section{References}


Access Economics Pty Limited. 2009. The Australian education sector and the economic contribution of international students: Australian Council for Private Education and Training.

Australian Education International (AEI). 2011. Export Income to Australia from Education Services in 2009-10 2011 [cited 12 May 2011]. Available from https://aei.gov.au/AEI/PublicationsAndResearch/Snapshots/Default.htm.

—. 2011. International Student Data 2011 [cited 12 May 2011]. Available from https://aei.gov.au/AEI/Statistics/StudentEnrolmentAndVisaStatistics/Default.h tm\#data.

Baas, Michiel. 2010. Imagined Mobility: Migration and Transnationalism among Indian Students in Australia. London: Anthem Press.

Dunn, Kevin M., Danielle Pelleri, and Maeder-Han Karin. 2011. Attacks on Indian students in Australia: the commerce of denial in Australia. Race \& Class 52 (4):71-88.

Hage, Ghassan. 2008. Analysing multiculturalism today. In The Sage Handbook of Cultural Analysis, edited by T. Bennett and J. Frow. Los Angeles: Sage.

Levitt, Peggy, and Nina Glick Schiller. 2004. Conceptualizing Simultaneity: A Transnational Social Field Perspective on Society. International Migration Review 38 (3):1002-1039.

Marginson, Simon, Christopher Nyland, Erlenawati Sawir, and Helen Forbes-Mewett. 2010. International Student Security. Port Melbourne: Cambridge University Press.

Markus, Andrew. 2010. Public opinion divided on populat ion, immigrat ion and asylum. Policy Magazine 26 (3):7-13.

Markus, Andrew, James Jupp, and Peter McDonald. 2009. Australia's Immigrant Revolution. Crows Nest, NSW: Allen \& Unwin.

Simmons, Alan B. 1999. Economic integration and designer immigrants: Canadian policy in the 1990s. In Free Markets, Open Societies, Closed Borders? Trends in International Migration and Immigration, edited by M. Castro. Miami: North-South Press, University of Miami.

Singh, Supriya, and Anuja Cabraal. 2010. Indian student migrants in Australia: Issues of community sustainability. People and Place 18 (1):19-30. 